http://ejournal.undip.ac.id/index.php/kapal

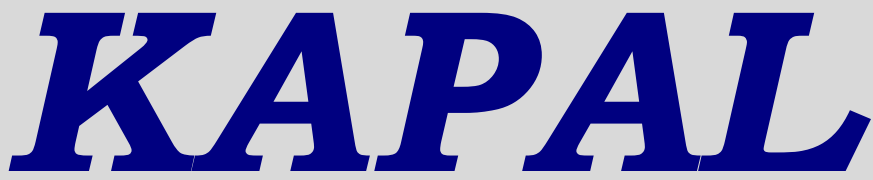

\title{
Studi Eksperimen Ketahanan Korosi, Keausan, dan Kekerasan pada Material Baja Paduan SS 316 Sebagai Bahan Sterntube Seal Liners pada Kapal
}

\author{
Muhammad Annas Pratama ${ }^{\left.1)^{*}\right)}$ \\ ${ }^{1)}$ Departemen Teknik Perkapalan, Fakultas Teknik, Universitas Diponegoro \\ Jl. Prof. Soedarto, SH, Kampus Undip Tembalang, Semarang, Indonesia 50275
}

diajukan pada:06/03/18 direvisi pada :09/04/19 diterima pada : 11/04/19

\begin{abstract}
Abstrak
Kegagalan sistem propulsi khususnya pada bagian tailshaft dan aft-end, sebagian besar terjadi dengan kasus berupa masuknya atau merembesnya air laut. Kegagalan ini disebabkan oleh beberapa hal, salah satunya ialah keausan pada Liners akibat mengalami kontak dengan objek asing selama perputaran poros. Baja paduan SS 316 merupakan paduan dengan sifat ketangguhan yang baik, serta tahan terhadap korosi sehingga umum diaplikasikan pada industri marine. Penelitian ini bertujuan untuk mengetahui nilai kekerasan, kemampuan ketahanan aus, serta korosi daripada paduan SS 316 untuk dijadikan material Liners dengan tolak ukur regulasi dan penelitian-penelitian yang telah dilakukan sebelumnya. Penelitian dilaksanakan dengan melakukan pembuatan spesimen uji sesuai dengan standar ASTM yang kemudian diuji di Laboratorium DTMI UGM seusai prosedur pengujian Kekerasan Rockwell, Keausan, dan Korosi. Setelah dilakukan pengujian, didapatkan nilai kekerasan sebesar 84 HRB untuk nilai tertinggi, dengan rata-rata tertinggi sebesar 82.33 HRB serta pengikisan kedalaman akibat keausan rata-rata sebesar 0.2405 mm/jam. Sedangkan untuk pengujian korosi didapatkan laju korosi sebesar $1.2065 \times 10^{-3} \mathrm{~mm} /$ year. Dengan demikian, disimpulkan untuk ketahanan korosi dikategorikan Oustanding, namun nilai kekerasan paduan SS 316 dianggap belum cukup untuk dapat dikategorikan fair terhadap ketahanan aus, sehingga diperlukan perlakuan khusus untuk meningkatkan kekerasan paduan SS 316, yang nantinya berdampak pada kemampuan material dalam menghadapi keausan.
\end{abstract}

Copyright $@ 2019, \mathbf{K A P A L}, 1829-8370$ (p), 2301-9069(e)

Kata Kunci :SS 316, Liners, Kekerasan, Korosi, Keausan

\section{PENDAHULAN}

Berdasarkan penelitian yang diadakan oleh Lloyd's Register mengenai kegagalan pada sistem propulsi, sebesar $24 \%$ terjadi pada bagian Forward Seal yang terdapat pada kamar mesin, serta sebesar $43 \%$ terjadi pada Aft Seal yang berada pada ceruk buritan dan langsung berhubungan laut [1]. Secara umum kegagalan sistem pada sistem propulsi terjadi pada bagian aft-Seal, dan kasus yang seing terjadi ialah masuknya atau merembesnya air laut akibat terjadinya kebocoran pada bagian tersebut [2].

\footnotetext{
*) Penulis Korespondensi :
}

Email : Muhammad_Annas_Pratama@yahoo.com
Secara teori apabila terdapat kotoran, pasir, atau objek asing yang masuk di sela-sela Rubber Seal dan Liners maka objek asing tersebut ikut mengalami kontak dengan permukaan Seal Liners, sehingga memungkinkan Seal Liners mengalami keausan. Selain itu instalasi Aft-Seal berinterkasi langsung dengan air laut, sehingga sangat rentan terhadap korosi yang dapat mengakibatkan kerusakan pada komponen. Oleh sebab itu sangat diperlukan penelitian untuk mensimulasikan serta melakukan analisa proses keausan pada Liner, sehingga dapat memprediksi ketahanan material sebagai bahan Sterntube Seal Liners kapal. 
Pada penelitian Eko S. [3], telah dilakukan penelitian kontak Rolling-Sliding. Kontak RollingSliding merupakan suatu peristiwa dimana suatu benda mengalami kontak rolling, namun dengan kecepatan yang tidak sama [3]. Akibatnya terjadilah slip saat peristiwa kontak rolling-sliding terjadi. Slip yang diakibatkan oleh peritiwa kontak tersebut dapat menimbulkan keausan. Pada penelitian tersebut, membahas suatu pendekatan yang dapat digunakan untuk menghitung kedalaman keausan akibat terjadinya kontak rolling-sliding. Dengan menggunakan pendekatan kontak rolling-sliding dalam pembahasan, dimaksudkan agar dapat digunakan untuk mensimulasikan kasus terjadinya keausan pada Seal Liners kapal.

Dengan latar belakang diatas, maka tujuan daripada penelitian ini ialah untuk mengetahui Nilai Kekerasan, Ketahanan Korosi, Keausan Spesifik serta Ketahanan Aus yang kemudian digunakan untuk menganalisa sifat mekanis paduan. Sehingga nantinya dapat disimpulkan layak atau tidaknya baja SS 316 sebagai material utama Sterntube Seal Liner pada kapal.

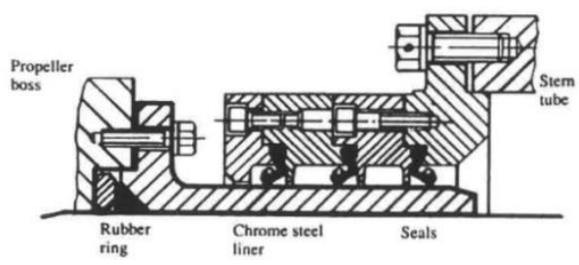

Gambar 1. Pemasangan Outboard Sterntube Lip Seal

\section{METODE}

\subsection{Pengumpulan Data}

Dasar teori dan sumber rujukan berasal dari buku-buku, majalah, modul, artikel, jurnal dan melalui internet. Sehingga dapat mempelajari karakteristik material baja paduan SS 316, serta mempelajari pengujian Kekerasan, Keausan, dan Korosi. Data utama didapatkan dari hasil pengujian. Adapun objek penelitian ialah baja paduan SS 316. SS 316 merupakan logam yang dikategorikan sebagai Mild steel juga tergolong sebagai baja nirkarat atau stainless steel. Hal yang membedakan antara baja nirkarat dengan baja biasa ialah, pada baja nirkarat terdapat sejumlah besar kandungan Krom dan Nickel yang memberikan sifat tahan korosi pada baja.

Sifat tahan korosi pada stainless steel tidak serta merta membuat stainless steel tidak dapat terserang korosi, karena pada kenyataannya stainless steel dapat mengalami korosi batas butir (intergranuler corrosion), korosi lubang (crevice corrosion), dan retakan korosi tegangan (stress corrosion cracking) [4]. Adapun kandungan utama SS 316 ialah Besi (Fe), Karbon (C), Nikel (Ni), serta Krom (Cr). Baja SS 316, memiliki kandungan paduan baja dengan Krom (Cr) hingga sebesar $18 \%$, Nikel (Ni) hingga Sebesar $14 \%$, dan unsur-unsur lain hingga $100 \%$.

Pada penelitian ini, diperlukan cairan elektrolit untuk memicu terjadinya peristiwa oksidasi pada material uji dalam pengujian korosi. Cairan elektrolit pada pengujian korosi, merupakan campuran aquadest dengan senyawa yang bersifat korosif. Cairan elektrolit akan dibuat berdasarkan kandungan $\mathrm{NaCl}$ di pesisir pantai Indonesia. Kandungan unsur yang terdapat pada air laut yang diambil dari pantai Aceh, Tanjung Mas dan Samas menunjukkan kandungan natrium khlorida $(\mathrm{NaCl})$ yang hampir sama yaitu sekitar $3 \%$ [5].

Pada penelitian ini pengujian dilaksanakan di Laboratorium bahan teknik DTMI UGM, juga terdapat simulasi perhitungan keausan pada Seal Liners dengan asumsi dimensi diameter Liner 600 $\mathrm{mm}$, diameter maksimum poros propeller sebesar $570 \mathrm{~mm}$, sehingga memiliki ketebalan dinding terusan Liners $30 \mathrm{~mm}$. Diasumsikan juga material diaplikasikan sebagai material Sterntube Seal Liner yang beroperasi pada draught $10 \mathrm{~m}$, dan RPM poros sebesar 100 RPM Serta menggunakan regulasi Lloyd's Register sebagai tolak ukur perhitungan ketebalan dinding Seal Liners. [6]

\subsection{Parameter Penelitian}

Terdapat beberapa parameter yang dijadikan tolak ukur dan batasan dalam penelitian yang akan dilakukan, baik dari jenis pengujian yang dilakukan maupun jenis standarisasi pembuatan spesimen uji. Adapun beberapa parameter yang digunakan dalam penelitian ini ialah:

\section{Uji Komposisi Unsur}

Merupakan pengujian yang dilakukan untuk mengatahui kandungan unsur secara detil. Fungsi daripada pengujian komposisi in adalah sebagai rujukan dalam menghitung nilai $E Q$ dalam pengujian korosi.

\section{Uji Kekerasan Rockwell}

Pada pengujian kekerasan metode Rockwell, pengujian dikelompokkan berdasarkan skala menurut jenis material yang akan diuji. Skala ini juga menentukan jenis indentor serta besaran nilai kekerasan yang akan didapatkan. Pada penelitian ini pengujian akan menggunakan Rockwell Skala B dengan beban total sebesar $100 \mathrm{Kgf}$ dan Intendor berupa bola baja berukuran 1/16". 


\section{Uji Keausan}

Metode Uji Keausan yang digunakan untuk penelitian ini ialah mengacu pada metode yang dilakukan oleh Selcuk, yaitu interaksi material padat yang digesekkan pada disk yang berputar (plate-on-disc) [7]. Pada penelitian ini spesimen digesek dengan beban $2.12 \mathrm{kgf}$, jarak pengaus sebesar 66.6 meter, dengan variasi waktu bervariatif dari $30,45,60,120$, dan 240 detik. Adapun formula untuk menghitung keausan spesifik menggunakan persamaan $1:[8]$

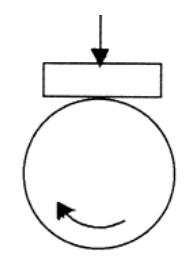

Gambar 2. Pengujian keausan plate-on-disc

$$
W s=\frac{B \cdot b o^{3}}{8 \cdot r \cdot P o \cdot L o}
$$

Dimana, Ws ialah nilai spesifik keausan $\left(\mathrm{mm}^{2} / \mathrm{kgf}\right)$, B ialah tebal piringan pengaus $(\mathrm{mm})$, bo adalah lebar keausan spesimen (mm), Po ialah Pembebanan saat uji keausan (kgf), dan Lo adalah jarak tempuh saat proses pengausan $(\mathrm{m})$.

Pengujian keausan juga digunakan pendekatan rumus kontak Rolling-Sliding untuk melakukan perhitungan simulasi keausan pada persamaan 2. [9]

$$
\frac{h w}{s}=\mathrm{Kd} . \mathrm{P}
$$

Dimana, hw ialah kedalaman keausan (mm), s ialah jarak Sliding $(\mathrm{mm}), \mathrm{Kd}$ ialah koefisien keausan berdimensi/Keausan Spesifik $\left(\mathrm{mm}^{2} / \mathrm{Kgf}\right)$, dan $\mathrm{P}$ adalah Tekanan Kontak $\left(\mathrm{Kgf} / \mathrm{mm}^{2}\right)$

Sedang untuk tekanan kontak, didapatkan dengan menggunakan persamaan tekanan hidrostatis dengan menggunaan persamaan 3 .

$$
\mathrm{P}=\rho \cdot \mathrm{g} . \mathrm{h}
$$

Dimana, $\mathrm{P}$ adalah tekanan $\left(\mathrm{Kgf} / \mathrm{mm}^{2}\right), \rho$ ialah massa jenis air laut $\left(1025 \mathrm{Kg} / \mathrm{m}^{3}\right), \mathrm{g}$ adalah percepatan gravitasi $\left(9.807 \mathrm{~m} / \mathrm{s}^{2}\right)$, dan $\mathrm{h}$ ialah kedalaman $(\mathrm{m})$

\section{Uji Korosi}

Pengujian korosi pada peneitian ini berfungsi untuk menghitung laju korosi menggunakan metode elektrokimia potentiodynamic yang mana untuk menghitung nilai $E Q$ dari suatu logam paduan ialah pada persamaan 4. dan 5. : [10]

$$
\begin{gathered}
\mathrm{EW}=\mathrm{N}_{\mathrm{EQ}}{ }^{-1} \\
\mathrm{~N}_{\mathrm{EQ}}{ }^{-1}=\sum\left[\frac{\omega_{i}}{a_{i} / n_{i}}\right]=\sum\left[\frac{\omega_{i} n_{i}}{a_{i}}\right]
\end{gathered}
$$

Dimana, $E$ ialah berat equivalen, $N_{E Q}$ ialah nilai equivalen total, $\omega_{i}$ adalah fraksi berat, $a_{i}$ ialah nomor massa atom, dan $n_{i}$ adalah elektron valensi

Setelah didapatkan nilai berat ekuivalennya (Equivallent Weight) maka selanjutnya dapat menghitung laju korosi dengan menggunakan persamaan 6. [11]

$$
\begin{gathered}
r=0,129 \frac{a i}{n D} \\
r=0,129 \frac{i_{\text {corr }}(E W)}{D}
\end{gathered}
$$

atau

Dimana, $r$ ialah laju korosi (mpy), a ialah nomor massa atom, i adalah rapat arus korosi $\left(\mu \mathrm{A} / \mathrm{cm}^{2}\right), \mathrm{n}$ adalah valensi atom, dan $\mathrm{D}$ ialah berat jenis specimen $\left(\mathrm{gr} / \mathrm{cm}^{3}\right)$

\section{Dimensi Spesimen}

Standar yang digunakan dalam membuat spesimen ialah ASTM, yang mana dimensi spesimen ialah sebagai berikut :

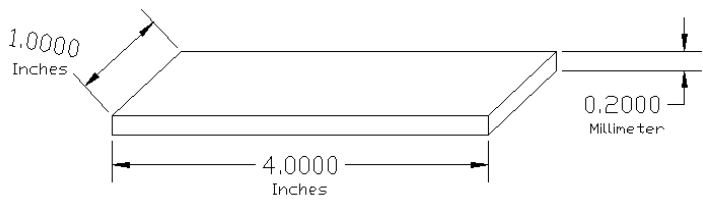

Gambar 3. Bentuk spesimen uji kekerasan dan keausan [12] [13]

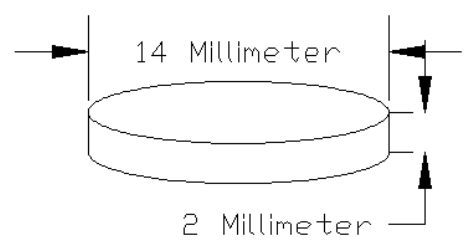

Gambar 4. Bentuk spesimen uji korosi [14]

\subsection{Peralatan dan Bahan Penelitian}

Peralatan penelitian berupa sarana peralatan yang digunakan dalam pembuatan spesimen maupun pengambilan data.

\section{Peralatan}

1. Raw Material SS 316

2. Mesin Bubut

3. Mesin Pemotong Hydraulic

4. Ogoshi Wear Testing Machine

5. Mesin Uji Kekerasan

6. Timbangan Scientific

7. Gelas Ukur, Gelas Beker, \& Tabung Labu 


\section{Bahan}

1. Aquadest

2. Serbuk $\mathrm{NaCl}$

3. Pasta Pemoles Logam (Autosol)

4. Alkohol

5. Kertas Ampelas 320 grit, 600 grit, 1000 grit, 1500 grit, dan 2000 grit

\section{HASIL DAN PEMBAHASAN}

\subsection{Hasil Uji Komposisi Unsur}

Data-data yang diperoleh dari studi karakterisasi material paduan SS 316 yang selanjutnya digunakan sebagai data acuan dalam proses pengujian selanjutnya, khususnya dalam perhitungan uji korosi. Hasil yang diperoleh dari pengujian ialah sebagai berikut.

Tabel 1. Hasil Uji Komposisi

\begin{tabular}{ccc}
\hline No & Unsur & \% Kandungan Unsur \\
\hline 1. & $\mathrm{C}$ & 0.0549 \\
2. & $\mathrm{Si}$ & 0.4711 \\
3. & $\mathrm{~S}$ & 0.0007 \\
4. & $\mathrm{P}$ & 0.0298 \\
5. & $\mathrm{Mn}$ & 0.9600 \\
6. & $\mathrm{Ni}$ & 8.0778 \\
7. & $\mathrm{Cr}$ & 17.4286 \\
8. & $\mathrm{Mo}$ & 0.0896 \\
9. & $\mathrm{Cu}$ & 0.1442 \\
10. & $\mathrm{~W}$ & 0.1610 \\
11. & $\mathrm{Ti}$ & 0.0052 \\
12. & $\mathrm{Sn}$ & 0.0113 \\
13. & $\mathrm{Al}$ & 0.0110 \\
14. & $\mathrm{Nb}$ & 0.0211 \\
15. & $\mathrm{~V}$ & 0.0538 \\
16. & $\mathrm{Co}$ & 0.2394 \\
17. & $\mathrm{~Pb}$ & 0.0000 \\
18. & $\mathrm{Ca}$ & 0.0005 \\
19. & $\mathrm{Zn}$ & 0.0486 \\
20. & $\mathrm{Fe}$ & 72.34 \\
\hline
\end{tabular}

Pada Tabel 1, dapat dilihat bahwa kandungan karbon yang kecil pada paduan SS 316 menjadikan SS 316 tergolong sebagai Mild Steel.

\subsection{Hasil Pengujian Kekerasan}

Setelah dilakukan pengujian, didapatkan nilai kekerasan benda uji pada setiap spesimen memiliki nilai yang sedikit berbeda. Adapun perolehan nilai hasil uji kekerasan, ditunjuk kan pada Tabel 2 dan Tabel 3.
Tabel 2. Hasil Uji Kekerasan (dalam HRB)

\begin{tabular}{cccc}
\hline No Spesimen & Titik 1 & Titik 2 & Titik 3 \\
\hline 1 & 84 & 84 & 79 \\
2 & 81 & 82 & 83 \\
3 & 82 & 83 & 79 \\
4 & 82 & 82 & 82 \\
5 & 83 & 82 & 82 \\
\hline
\end{tabular}

Tabel 3. Rata-rata Nilai Kekerasan (dalam HRB)

\begin{tabular}{cc}
\hline No Spesimen & Rata-rata \\
\hline 1 & 82.33 \\
2 & 82 \\
3 & 81 \\
4 & 82 \\
5 & 82.33 \\
\hline
\end{tabular}

Dari tabel 3. didapatkan nilai kekerasan maksimal untuk nilai kekerasan rata-rata sebesar 82.33 HRB. Adapun nilai kekerasan maksimal menurut tabel 2 ialah sebesar 84 HRB. Menurut jurnal Review of the Wear and Galling Characteristics of Stainless Steels [15], material Stainless Steel dapat dikatakan Fair atau cukup dalam ketahanan terhadap keausan tanpa pelumas, setidaknya memiliki nilai kekerasan sebesar 12.5 HRC atau bila dikonversikan ke dalam skala HRB bernilai sebesar 91 HRB. Dengan demikian nilai kekerasan material belum dapat dikatakan fair untuk menghadapi keausan.

\subsection{Hasil Pengujian Keausan}

Besarnya jejak permukaan dari spesimen yang tergesek dengan pembeda variasi waktu gesek didapatkan, kemudian besarnya jejak tersebut digunakan untuk menghitung keausan spesifik dengan menggunakan persamaan 1 [8].

$$
W s=\frac{B \cdot b o^{3}}{8 \cdot r \cdot P o \cdot L o}
$$

Sehingga didapatkan hasil keausan spesifik sebagai berikut :

Tabel 4. Data Hasil Uji Keausan Spesifik

\begin{tabular}{ccc}
\hline $\begin{array}{c}\text { Lama } \\
\text { Abrasi }\end{array}$ & $\begin{array}{c}\text { bo } \\
(\mathbf{m m})\end{array}$ & $\begin{array}{c}\text { Ws } \\
\left(\mathbf{m m}^{2} / \mathbf{k g f}\right)\end{array}$ \\
\hline 30 Detik & 0.9035 & $1.30591 \times 10^{-7}$ \\
45 Detik & 0.982 & $1.67673 \times 10^{-7}$ \\
60 Detik & 1.030 & $1.93482 \times 10^{-7}$ \\
120 Detik & 1.131 & $2.56163 \times 10^{-7}$ \\
240 Detik & 1.206 & $3.10578 \times 10^{-7}$ \\
\hline
\end{tabular}




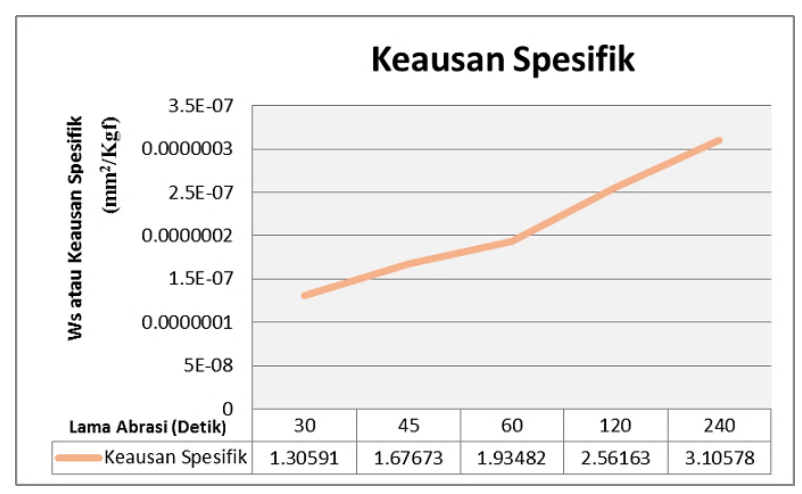

Gambar 5. Grafik hasil pengujian keausan spesifik

Selanjutnya menghitung tekanan kontak pada permukaan Liners menggunakan persamaan 3.

$$
P=\rho \cdot g \cdot h
$$

Hasilnya, didapatkan tekanan kontak sebesar $100.52175 \mathrm{~N} / \mathrm{m}^{2}$ atau $0.01025037 \mathrm{Kgf} / \mathrm{mm}^{2}$. Dengan asumsi bahwa diameter Seal Liner sebesar $600 \mathrm{~mm}$ dan RPM poros sebesar 100 RPM, maka didapatkan jarak sliding sebesar $11304000 \mathrm{~mm}$ dalam satu jam. Setelah didapatkan tekanan kontak dan jarak sliding selanjutnya menghitung pengkisan kedalaman dengan menggunakan persamaan 2. [9]

$$
\frac{h w}{s}=\mathrm{Kd} . \mathrm{P}
$$

Sehingga didapatkan hasil sebagai berikut

Tabel 5. Perhitungan Kedalaman Keausan per Jam

\begin{tabular}{ccc}
\hline No & $\begin{array}{c}\text { Keausan Spesifik } \\
\left(\mathbf{m m}^{2} / \mathbf{K g f}\right)\end{array}$ & $\begin{array}{c}\text { Kedalaman } \\
\text { Keausan }(\mathbf{m m})\end{array}$ \\
\hline 1 & $1.30591 \times 10^{-7}$ & $0.01513 \mathrm{~mm}$ \\
2 & $1.67673 \times 10^{-7}$ & $0.01943 \mathrm{~mm}$ \\
3 & $1.93482 \times 10^{-7}$ & $0.02242 \mathrm{~mm}$ \\
4 & $2.56163 \times 10^{-7}$ & $0.02968 \mathrm{~mm}$ \\
5 & $3.10578 \times 10^{-7}$ & $0.03599 \mathrm{~mm}$ \\
& Rata-rata & $0.02453 \mathrm{~mm}$ \\
\hline
\end{tabular}

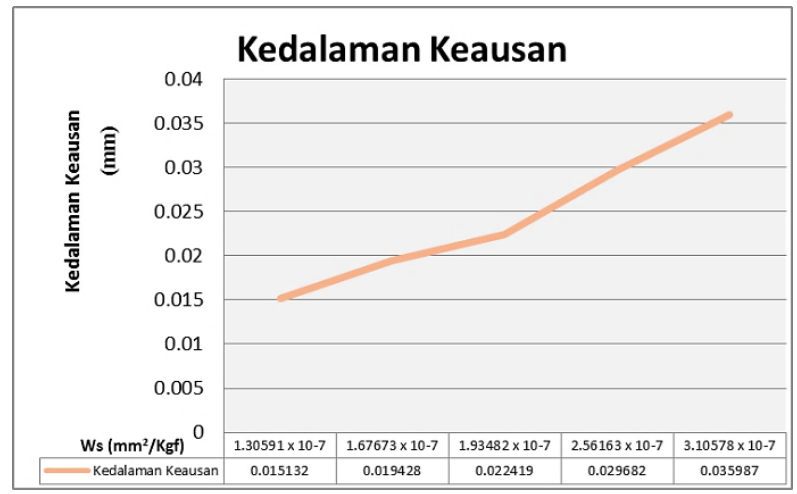

Gambar 6. Grafik hasil perhitungan kedalaman keausan per Jam
Tabel 6. Hasil Perhitungan Kedalaman Keausan per Putaran

\begin{tabular}{ccc}
\hline No & $\begin{array}{c}\text { Jumlah } \\
\text { Putaran }\end{array}$ & $\begin{array}{c}\text { Kedalaman Keausan } \\
(\mathbf{m m})\end{array}$ \\
\hline 1 & $1 \times 10^{5}$ & $0.408824723 \mathrm{~mm}$ \\
2 & $2 \times 10^{5}$ & $0.817649446 \mathrm{~mm}$ \\
3 & $4 \times 10^{5}$ & $1.635298892 \mathrm{~mm}$ \\
4 & $6 \times 10^{5}$ & $2.452948339 \mathrm{~mm}$ \\
5 & $8 \times 10^{5}$ & $3.270597785 \mathrm{~mm}$ \\
6 & $10 \times 10^{5}$ & $4.088247231 \mathrm{~mm}$ \\
7 & $12 \times 10^{5}$ & $4.905896677 \mathrm{~mm}$ \\
8 & $14 \times 10^{5}$ & $5.723546123 \mathrm{~mm}$ \\
\hline
\end{tabular}

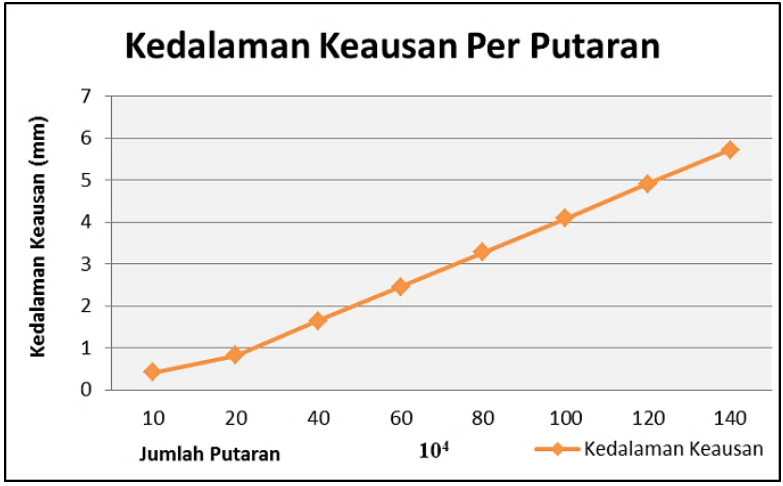

Gambar 7. Grafik hasil perhitungan kedalaman keausan per putaran

Selanjutnya ialah mensimulasikan terjadinya keausan pada Liner dan menerapkan Rules Lloyd's Register menggunakan persamaan 7. [6]

$$
t=\frac{D+230}{32} \mathrm{~mm}
$$

Dimana $\mathrm{t}$ adalah tebal minimal Liner yang dibutuhkan, dan D ialah diameter Propeller Shaft.

Ketebalan yang dipersyaratkan oleh regulasi ialah $25 \mathrm{~mm}$. Jadi, diperkirakan Liner dapat bertahan menurut regulasi yang telah ditetapkan, selama kurang lebih 200 jam sejak awal kontak.

\subsection{Hasil Pengujian Korosi}

Pada pengujian korosi, material diuji dengan dimasukkan ke dalam tabung labu yang berisi cairan elektrolit, kemudian diberi beda potensial sehingga terjadi peristiwa korosi sehingga didapatkan hasil pada tabel 7 dan Gambar 8.

Tabel 7. Data Hasil Pengujian Korosi

\begin{tabular}{cc}
\hline Variabel & Nilai \\
\hline $\mathrm{E}(\mathrm{I}=0)$ & $-125.301 \mathrm{mV}$ \\
Icorr & $92.385 \mathrm{nA}$ \\
Cathodic Beta & $125.801 \mathrm{mV}$ \\
Anodic Beta & $435.219 \mathrm{mV}$ \\
\hline
\end{tabular}




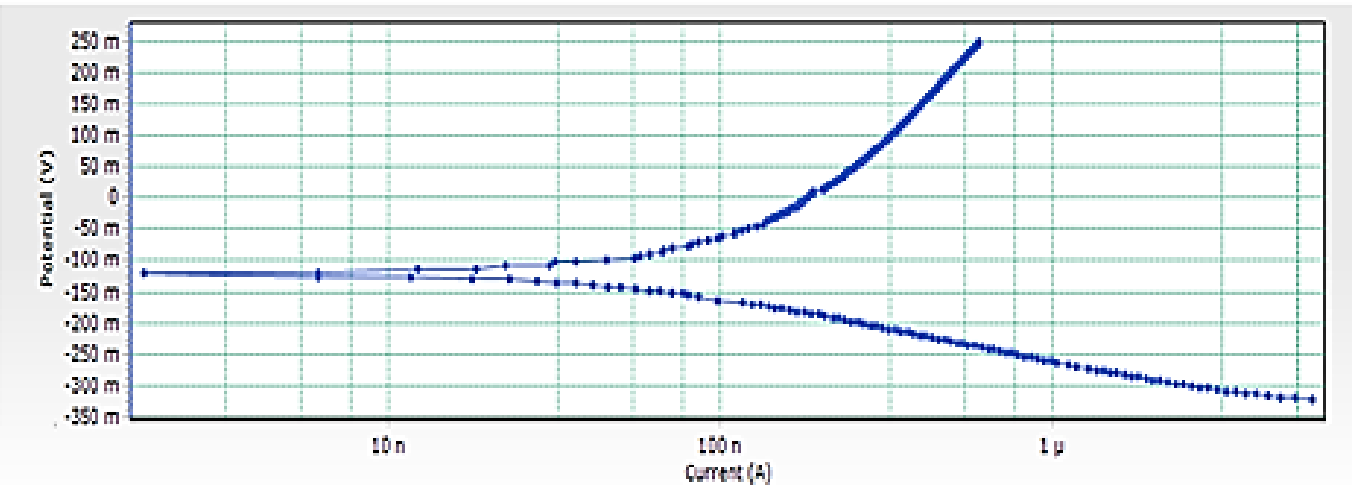

Gambar 8. Grafik Potential (V) vs Current (A)

Selanjutnya ialah menghitung nilai $N_{E Q^{-1}}$ dengan menggunakan data dari Tabel 1 dan Tabel periodik unsur untuk menghitung nilai $N_{E Q^{-I}}$ dengan menggunakan persamaan 5. [10]

$$
\mathrm{N}_{\mathrm{EQ}}{ }^{-1}=\sum\left[\frac{\omega_{i}}{a_{i} / n_{i}}\right]=\sum\left[\frac{\omega_{i} n_{i}}{a_{i}}\right]
$$

Sehinggadidapatkan hasil sebegai berikut :

Tabel 8. Nilai Equivalen Total

\begin{tabular}{ccc}
\hline No & Unsur & Nilai Equivalen Total \\
\hline 1. & $\mathrm{C}$ & 0.00018283 \\
2. & $\mathrm{Si}$ & 0.00067094 \\
3. & $\mathrm{~S}$ & 0.00000131 \\
4. & $\mathrm{P}$ & 0.00004810 \\
5. & $\mathrm{Mn}$ & 0.00034948 \\
6. & $\mathrm{Ni}$ & 0.00275256 \\
7. & $\mathrm{Cr}$ & 0.00335191 \\
8. & $\mathrm{Mo}$ & 0.00001868 \\
9. & $\mathrm{Cu}$ & 0.00002269 \\
10. & $\mathrm{~W}$ & 0.00001752 \\
11. & $\mathrm{Ti}$ & 0.00000217 \\
12. & $\mathrm{Sn}$ & 0.00000190 \\
13. & $\mathrm{Al}$ & 0.00001223 \\
14. & $\mathrm{Nb}$ & 0.00000454 \\
15. & $\mathrm{~V}$ & 0.00002112 \\
16. & $\mathrm{Co}$ & 0.00008124 \\
17. & $\mathrm{~Pb}$ & 0.0000 \\
18. & $\mathrm{Ca}$ & 0.00000025 \\
19. & $\mathrm{Zn}$ & 0.00001487 \\
20. & $\mathrm{Fe}$ & 0.02590742 \\
\hline
\end{tabular}

Selanjutnya menggunakan Persamaan 4 [10]

$$
\mathrm{EW}=\mathrm{N}_{\mathrm{EQ}}{ }^{-1}
$$

Didapatkan nilai EW sebesar 29.8848. Selanjutnya menghitung laju korosi guna menentukan kategori ketahanan korosi dari paduan SS 316 dengan menggunakan persamaan 6 [11].

$$
r=0,129 \frac{i_{\text {corr }}(E W)}{D}
$$

Didapatkan nilai laju korosi sebesar 0.0475 mpy atau bila dikonversikan menjadi satuan metriks ialah sebesar $1.2065 \times 10^{-3} \mathrm{~mm} /$ year . Menurut D.A Jones, laju korosi dapat dikategorikan sebagai berikut : [11]

\begin{tabular}{|c|c|c|c|c|c|}
\hline $\begin{array}{c}\text { Relative } \\
\text { Corrosion } \\
\text { Resistance }\end{array}$ & $\begin{array}{c}m p \\
y\end{array}$ & $\frac{m m}{y e a r}$ & $\frac{\mu m}{y e a r}$ & $\frac{n m}{y e a r}$ & $\frac{p m}{\text { year }}$ \\
\hline $\begin{array}{c}\text { Outstandin } \\
g\end{array}$ & $<1$ & 2 & $<25$ & $<2$ & $<1$ \\
\hline Excelent & $1-5$ & $\begin{array}{c}0,02- \\
0,10\end{array}$ & $\begin{array}{l}25 \\
10\end{array}$ & 2 & $<1$ \\
\hline Good & 2 & & $\begin{array}{l}100- \\
500\end{array}$ & 50 & 50 \\
\hline Fair & $\begin{array}{c}20- \\
50\end{array}$ & $\begin{array}{c}0,50- \\
1,00\end{array}$ & $\begin{array}{l}500- \\
1000\end{array}$ & $\begin{array}{l}50- \\
150\end{array}$ & $\begin{array}{l}50- \\
150\end{array}$ \\
\hline
\end{tabular}

Tabel 9. Perbandingan ketahanan korosi dalam mpy dan metric

Sehingga hasil laju korosi untuk material SS 316 dikategorikan sebagai material yang Outstanding (Mengagumkan) dalam ketahanannya terhadap korosi.

\section{KESIMPULAN}

Hasil pengujian kekerasan baja paduan SS 316 dengan menggunakan metode Rockwell skala B menghasilkan tingkat kekerasan yang cukup homogen. Nilai kekerasan dari material baja paduan SS 316 tanpa perlakuan khusus memiliki nilai rata-rata sebesar $81 \mathrm{HRB}, 82 \mathrm{HRB}$, dan 82.33 HRB dengan nilai tertinggi sebesar 84 HRB. Belum memenuhi nilai kekerasan minimal untuk dapat dikategorikan fair terhadap keausan yang mana untuk dapat dikategorikan fair, dibutuhkan nilai kekerasan sebesar 12.5 HRC atau 91 HRB. 
Hasil pengujian keausan baja paduan SS 316 dengan variasi waktu abrasif menghasilkan harga nilai keausan abrasif yang cukup bervariatif. Didapatkan nilai pengikisan kedalaman rata-rata sebesar $0.02453 \mathrm{~mm} / \mathrm{Jam}$. Merujuk pada regulasi Lloyd's Register yang mengharuskan memiliki ketebalan minimal $25 \mathrm{~mm}$ untuk beroperasi, maka Liner dapat bertahan dengan ketebalan diatas 25 mm selama kurang lebih 200 jam setelah kontak.

Hasil pengujian laju korosi baja paduan SS 316, pada elektrolit $\mathrm{NaCl} 3.5 \%$ dengan metode Polarisasi Potentiodynamic, didapatkan icorr sebesar $92.385 \mathrm{nA}$. Kemudian dihitung nilai laju korosi daripada baja paduan SS 316 dan dihasilkan nilai sebesar 0.0475 mpy yang kemudian dikonversikan ke dalam satuan matriks menjadi $1.2065 \times 10^{-3} \mathrm{~mm} /$ year, dan dapat dikategorikan memiliki kemampuan Oustanding dalam ketahanan terhadap korosi.

\section{DAFTAR PUSTAKA}

[1] Thornhill, John Bsc. "The Challenge of Stern Tube Bearings and Seals". Jurnal Society of Naval Architect and Marine Engineers. : unpublished.

[2] Heck, J.W. dan Baker, E. 1963. "Marine Propeller Shaft Casualties". New York. Transactions of Society of Naval Architect and Marine Engineers. Vol. 71. pp. 327-346.

[3] Saputra, E. dkk. 2011. "Perhitungan Keausan pada Kontak Rolling-Sliding". Seminar Nasional Teknologi Informasi \& Komunikasi Terapan (Semantik).

[4] Ornelasari, R. 2015. "Analisa Laju Korosi Pada Stainless Steel 304 Menggunakan Metode ASTM G31-72 Pada Media Air Nira Aren". Jurnal Teknik Mesin Universitas Negeri Surabaya. Volume 01 Nomor 01 Tahun 2015, 112-117.

[5] Ispandriatno, A.S. dan Krisnaputra, R. 2015. "Ketahanan Korosi Baja Ringan di Lingkungan Air Laut”. Jurnal Teknologi Material Proses, Volume 1, Nomor 1, Universitas Gadjah Mada.

[6] Lloyd's Register. 2016. "Lloyd's Regulations for the classification of ships" Part 5 Ch.6 Section 3

[7] Selcuk, B., Ipek, R. dan Karamis M.B. 2003. "A Study on Friction and Behaviour of Carburized, Carbonitrided and Borided AISI 1020 and 5115 Steel". Journal of Materials Processing Technology. Vol 141
[8] Tokyo Testing Machine Mfg. Co., Ltd. Ogoshi High Speed Universal Wear Testing Machine Instruction Manual. Manual Instruction Book. : unpublished.

[9] J.F. Archard. 1980. Wear theory and mechanisms. In: Peterson MB, Winer WO, editors. Wear control handbook. New York: ASME.

[10] Möller, H. 2006. "The Corrosion Behaviour of Steel in Sea Water". The Shoutern African Institute of Mining and Metallurgy 8th. International Corrosion Conference.

[11] Jones, D.A.. 1991. Principles and Prevention of Corrosion. McMillan Publishing Company. New York

[12] ASTM Standards. E18-15. "Standard Test Method for Rockwell Hardness of Metallic Materials". Philadelphia. American Standard Testing and Material.

[13] ASTM Standards. G-65. "Standard Test Method for Measuring Abrasion Using the Dry Sand/Rubber Wheel Apparatus". Philadelphia. American Standard Testing and Material.

[14] ASTM Standards. G-31. "Practice for Laboratory Immersion Corrosion Testing of Metals". Philadelphia. American Standard Testing and Material.

[15] Committee of Stainless Steel Producers. American Iron and Steel Institute. 1978. "Review of the Wear and Galling Characteristics of Stainless Steel". Washington. DC. Committee of Stainless Steel Producers. American Iron and Steel Institute. 